\title{
Field Evaluations of Leaf Spot Resistance and Yield in Peanut Genotypes in the United States and Bolivia
}

\author{
S. K. Gremillion, Department of Biology, Armstrong Atlantic State University, Savannah, GA 31419; A. K. Culbreath, Department of \\ Plant Pathology, University of Georgia Coastal Plain Experiment Station, Tifton 31793; D. W. Gorbet, Agronomy Department, Univer- \\ sity of Florida North Florida Research and Education Center, Marianna 32446; B. G. Mullinix, Jr., Research Statistician, Texas A\&M \\ University, Lubbock 79424; R. N. Pittman, United States Department of Agriculture-Agricultural Research Service, University of \\ Georgia Agricultural Experiment Station, Griffin 30223; K. L. Stevenson, Department of Plant Pathology, University of Georgia \\ Coastal Plain Experiment Station, Tifton 31793; J. W. Todd, Entomology Department, University of Georgia Coastal Plain Experiment \\ Station, Tifton; and R. E. Escobar and M. M. Condori, Asociacion de Productores de Oleaginosas y Trigo, Cas. 2305, Complejo \\ Semillero, Km. 81/2 Santa Cruz, Bolivia
}

\begin{abstract}
Gremillion, S. K., Culbreath, A. K., Gorbet, D. W., Mullinix, B. G., Jr., Pittman, R. N., Stevenson, K. L., Todd, J. W., Escobar, R. E., and Condori, M. M. 2011. Field evaluations of leaf spot resistance and yield in peanut genotypes in the United States and Bolivia. Plant Dis. 95:263-268.

Field experiments were conducted in 2002 to 2006 to characterize yield potential and disease resistance in the Bolivian landrace peanut (Arachis hypogaea) cv. Bayo Grande, and breeding lines developed from crosses of Bayo Grande and U.S. cv. Florida MDR-98. Diseases of interest included early leaf spot, caused by the fungus Cercospora arachidicola, and late leaf spot, caused by the fungus Cercosporidium personatum. Bayo Grande, MDR-98, and three breeding lines, along with U.S. cvs. C-99R and Georgia Green, were included in split-plot field experiments in six locations across the United States and Bolivia. Whole-plot treatments consisted of two tebuconazole applications and a nontreated control. Genotypes were the subplot treatments. Area under the disease progress curve (AUDPC) for percent defoliation due to leaf spot was lower for Bayo Grande and all breeding lines than for Georgia Green at all U.S. locations across years. AUDPC for disease

leaf spot epidemics and relative effects of the genotypes were less consistent in the Bolivian experiments. In Bolivia, there were no indications of greater levels of disease resistance in any of the breeding lines than in Bayo Grande. In the United States, yields of Bayo Grande and the breeding lines were greater than those of the other genotypes in 1 of 2 years. In Bolivia, low disease intensity resulted in the highest yields in Georgia Green, while high disease intensity resulted in comparable yields among the breeding lines, MDR-98, and C-99R. Leaf spot suppression by tebuconazole was greater in Bolivia than in the United States. This result indicates a possible higher level of fungicide resistance in the U.S. population of leaf spot pathogens. Overall, data from this study suggest that Bayo Grande and the breeding lines may be desirable germplasm for U.S. and Bolivian breeding programs or production.
\end{abstract} incidence from one U.S. location indicated similar results. Severity of
Peanut (Arachis hypogaea L.) offers both nutritional and economic benefits to the areas of the world where it is grown. However, crop production and financial returns are threatened yearly by destructive diseases. Among the most common and devastating fungal diseases of peanut are the leaf spots: early leaf spot caused by Cercospora arachidicola Hori and late leaf spot caused by Cercosporidium personatum (Berk. \& M.A. Curtis) Deighton (22). Both leaf spot diseases cause defoliation and compromise peg integrity, resulting in pod detachment at harvest and reduced yields.

The use of cultivars with partial resistance to these pathogens is an effective means of leaf spot management $(13,17,18)$. Although several cultivars currently available in the United States have partial resistance to one or more pathogens $(1,6,7)$, a recent evaluation of the peanut crop as a whole indicated an overall lack of genetic diversity and a classification of "vulnerable to diseases" (22). This rating is largely due to the few sources of parent germplasm used to produce U.S. cultivars (10). Peanut production in the United States is heavily dependent on the use of fungicides for control of leaf spot and other diseases. Incorporation of resistance from diverse sources into U.S. cultivars could help reduce the need for

Corresponding author: S. Gremillion

E-mail: Sara.Gremillion@armstrong.edu

Accepted for publication 1 October 2010.

doi:10.1094/PDIS-06-10-0454

(C) 2011 The American Phytopathological Society fungicides and should help increase the overall stability of resistance to pathogens.

Bolivia has been recognized as an underutilized source of genotypic diversity for Arachis spp. (11,25), and is noted by Holbrook and Stalker (9) as a center for resistance to both Cercospora arachidicola and Cercosporidium personatum in cultivated peanut. With one of its main objectives being to utilize Bolivia's diverse germplasm and potential disease resistance to develop improved cultivars for both the United States and Bolivia, the UFL-16 project of the United States Agency for International Development's Peanut Collaborative Research and Support Program (USAID Peanut CRSP) has developed a series of CRSP breeding lines from crosses of U.S. cv. Florida MDR-98 (MDR-98) and Bolivian landrace cv. Bayo Grande. MDR-98 has a moderate level of leaf spot resistance (8) compared with the standard runner-type cv. Georgia Green $(4,14,15)$. Similarly, Bayo Grande has shown much higher levels of resistance to Cercospora arachidicola and Cercosporidium personatum than Georgia Green in preliminary field evaluations (unpublished data).

Preliminary field evaluations of the U.S.-Bolivian germplasm narrowed selections to a group with the potential for cultivar or germplasm release in the United States or Bolivia. However, more information on the disease resistance and yield response of the CRSP breeding lines in multiple locations is needed to support final selection, because genotype-environment interactions are common when screening for resistance to early leaf spot $(12,16,23,24)$, late leaf spot (5), and yield potential (2). Objectives of this study were to evaluate leaf spot resistance and yield potential in Bayo Grande and a series of CRSP peanut breeding lines in field experiments at multiple locations in the United States 
and Bolivia conducted in collaboration with the Asociacion de Productores de Oleaginosas y Trigo (ANAPO). Emphasis was also placed on determining how breeding lines selected for resistance to leaf spot pathogens and for yield potential in the United States respond to pathogen populations and environmental conditions in Bolivia.

\section{Materials and Methods}

Disease and yield evaluations. Genotype evaluations for leaf spot resistance and yield potential were conducted at three U.S. locations, including the University of Georgia (UGA) Attapulgus Research and Education Center, Attapulgus (elevation $81 \mathrm{~m}$ ); the UGA Southwest Research and Education Center, Plains (elevation $152 \mathrm{~m}$ ); and the UGA Coastal Plain Experiment Station Lang Farm in Tifton (elevation $107 \mathrm{~m}$ ) in 2004 to 2005. Field experiments were also conducted in Bolivia, South America at the Centro Experimental de ANAPO (CEA-3), San Pedro, Obispo Santiestevan Province, Santa Cruz (elevation $223 \mathrm{~m}$ ) in 2005 during the typically dry, winter growing season (June to December); and the Centro de Investigación y Transferencia de Tecnología del Cultivo de la Caña de Azúcar (CITTCA), Saavedra, Obispo Santiestevan Province, Santa Cruz (elevation $320 \mathrm{~m}$ ), and the Centro Experimental de ANAPO (CEA-2), Veintiséis de Agosto, Nuflo de Chavez Province, Santa Cruz (elevation $340 \mathrm{~m}$ ) in the 2004-05 and 2005-06 seasons during the typically wet, summer growing seasons (December to May).

A split-plot design with three replications was used for all experiments. Fungicide regimes represented the whole-plot treatments and included: (i) nontreated control (0 sprays) and (ii) tebuconazole (TEB; Folicur 3.6F in the United States or Folicur 250 FC in Bolivia; Bayer CropScience, Research Triangle Park, NC) applied at the rate of $0.138 \mathrm{~kg}$ a.i./ha with an initial application at the first observation of leaf spot symptoms followed by a second application 14 days later (two sprays). The two-spray fungicide regime was used as a preventative measure to help separate host genotype resistance effects in case severe epidemics overcame host defenses. The fungicide rate was selected to emulate practices that Bolivian farmers might use. The typical rate used in the southeastern United States is $0.24 \mathrm{~kg}$ a.i./ha. Subplot treatments included cvs. MDR-98, Bayo Grande, C-99R, and Georgia Green and the CRSP breeding lines CRSP-01, CRSP-08, and CRSP-14. All breeding lines were in the $\mathrm{F}_{7}$ generation in 2004 and are considered late-maturing genotypes, typically requiring 145 to 150 days to maturity in Georgia. U.S. C-99R is a late-maturing cultivar with a moderate level of resistance to leaf spot $(4,7,14,15)$, and Georgia Green is a common medium-maturing cultivar grown in the southeastern United States that is susceptible to Cercospora arachidicola and Cercosporidium personatum $(4,14,15)$.

At the U.S. locations, peanut crops were planted on 26 May 2004 and 26 May 2005 in Attapulgus, 24 May 2004 and 25 May 2005 in Plains, and 20 May 2004 and 24 May 2005 in Tifton. All plots were planted at the rate of $16.4 \mathrm{seed} / \mathrm{m}$ in $1.8-$ by- $6.1-\mathrm{m}$ plots with two rows, $0.9 \mathrm{~m}$ apart. Plots were irrigated throughout the season as needed. In Bolivia, peanut crops were planted on 22 December 2004 and 7 December 2005 in Saavedra, on 15 December 2004 and 30 December 2005 in Veintiséis de Agosto, and on 23 June 2005 in San Pedro. All Bolivian plots consisted of two rows, $6 \mathrm{~m}$ in length with $0.07 \mathrm{~m}$ between the row and $0.07 \mathrm{~m}$ between plots. Plots did not receive any irrigation in addition to natural rain events.

In Attapulgus, leaf spot intensity was evaluated at approximately weekly intervals beginning 57 days after planting (DAP) and ending 138 DAP in 2004. The following year, leaf spot intensity was evaluated at approximately weekly intervals beginning 60 DAP and ending 141 DAP. In Plains, leaf spot was evaluated at approximately weekly intervals beginning 79 DAP and ending 140 DAP in 2004. The following year, disease was assessed at approximately weekly intervals beginning 61 DAP and ending 138 DAP. In Tifton, leaf spot intensity was evaluated at approximately weekly intervals beginning 68 DAP and ending 146 DAP in 2004.
The following year, disease was assessed at approximately weekly intervals beginning 62 DAP and ending 146 DAP. Across U.S. locations and years, George Green was harvested approximately 1 week before the other genotypes due to an earlier maturity phenotype; therefore, Georgia Green received one less disease intensity evaluation.

In the United States in 2004, Georgia Green plots were inverted 131 DAP at Attapulgus, 135 DAP at Plains, and 138 DAP in Tifton. The remaining genotypes were inverted 142 DAP in Attapulgus, 143 DAP in Plains, and 150 DAP in Tifton. In 2005, Georgia Green plots were inverted 141 DAP at Attapulgus, 128 DAP at Plains, and 140 DAP in Tifton. The remaining genotypes were inverted 147 DAP in Attapulgus, 142 DAP in Plains, and 153 DAP in Tifton. Peanut crops were harvested 7 to 10 days after digging at each location in both years.

In Saavedra, leaf spot intensity was evaluated 92, 104, and 124 DAP in 2005 and 74, 91, 102, and 115 DAP in 2006. At Veintiséis de Agosto, leaf spot intensity was assessed 83 and 114 DAP in 2005 and 72, 100, 114, 121, and 132 DAP in 2006. At San Pedro, leaf spot intensity was assessed 91, 134, and 160 DAP in 2005. All plots at Saavedra were inverted 141 DAP in 2005 and 124 DAP in 2006. All plots at Veintiséis de Agosto were inverted 132 DAP in 2005 and 136 DAP in 2006. All plots at San Pedro were inverted 170 DAP in 2005.

Leaf spot intensity was calculated as the average percent defoliation and was based on visual estimates for the entire subplot. Area under the disease progress curve (AUDPC) based on percent defoliation was calculated for each replication of genotype and fungicide treatment and standardized by dividing AUDPC by the number of days between the first and final leaf spot rating (3).

The effects of fungicide and genotype on AUDPC leaf spot intensity and yield were analyzed using SAS Proc MIXED (SAS v 9.1; SAS Institute, Inc. Cary, NC). The Satterthwaite option was used for determining degrees of freedom. Significant interactions were included in the model as random effects. Nonsignificant interactions $(P \leq 0.05)$ were removed from the model. If nonsignificant interactions contributed substantially to variation $(F$ value $>1.00)$, they were included as random effects. Differences among genotypes were determined based on results of the PDIFF option included in each main effect and significant interaction LSMEAN statement. Significant differences in AUDPC leaf spot intensity and yield among treatments were determined based on Fisher's protected least significant difference $(P \leq 0.05)$. Significance levels reported in the text are $P \leq 0.05$ unless otherwise indicated.

Predefoliation leaf spot evaluations. In the previously described field study, intensity of early and late leaf spot epidemics was assessed based on percent defoliation caused by those diseases. This evaluation, however, does not account for symptoms that appear at the beginning of epidemics, prior to the onset of defoliation. Because initial disease development early in the epidemic may provide important information about resistance, predefoliation early leaf spot evaluations were recorded along with defoliation data. Late leaf spot symptoms were not recorded because the delayed appearance of the disease often coincides with defoliation from early leaf spot in areas where both are found.

Field experiments were conducted at the UGA Rigdon Farm in Tifton in 2002 and 2003. The design was a randomized complete block experimental design with three replications. Host genotype was the experimental variable. Genotypes assessed included all those described previously plus CRSP-20, another line developed from a cross between Bayo Grande and MDR-98. Planting dates were 20 May 2002 and 21 May 2003. Seeding rate was 16.4 $\mathrm{seed} / \mathrm{m}$ of row. Plots were 1.8 by $6.1 \mathrm{~m}$ and consisted of two rows, $0.9 \mathrm{~m}$ apart. Once seedlings emerged, plots were reseeded manually as necessary to ensure an adequate stand. Plots were irrigated as needed.

For disease assessments, one lateral branch from each of 10 random plants was removed from each plot at 87, 95, 101, and 109 DAP in 2002 and 56, 63, 70, 77, 81, and 88 DAP in 2003. Disease 
was assessed on the first nine leaves, starting from the node closest to the main stem. Disease incidence was recorded as the percentage of leaves with one or more leaf spots or defoliation and averaged across the 10 lateral branches. AUDPC for disease incidence over time was calculated for each replication. The effect of genotype on AUDPC was determined using Proc MIXED. The Satterthwaite option was used to calculate degrees of freedom. Significant differences among genotypes for AUDPC were defined by Fisher's protected least significant difference $(P \leq 0.05)$. Significance level reported in the text is $P \leq 0.05$ unless otherwise indicated.

Environmental conditions. Environmental conditions varied greatly among years and locations. Rainfall data for the three U.S. locations was obtained from the Georgia Automated Environmental Monitoring Network, University of Georgia, Griffin (http://www.georgiaweather.net/). Rainfall totals for the duration of the experiments were 68 and $67 \mathrm{~cm}$ at Attapulgus in 2004 and 2005, respectively; 77 and $72 \mathrm{~cm}$ at Plains in 2004 and 2005, respectively; and 17, 49, 77, and $44 \mathrm{~cm}$ in 2004 to 2005, respectively, at Tifton. In 2004, all U.S. experiments were affected by the remnants of tropical storm Bonnie, and hurricanes Charley, Frances, Ivan, and Jeanne. In 2005, all U.S. experiments were affected by tropical storm Arlene, and Attapulgus and Plains locations received heavy rains from the remnants of hurricane Dennis. Although total rainfall was similar for 2004 and 2005 at Attapulgus and Plains, distribution of rainfall in 2005 made for conditions that were less favorable for disease development in 2005 than in 2004.

In Bolivia, conditions were recorded during all seasons. Conditions were dry during the 2004-05 season at Saavedra, with a total rainfall of $45 \mathrm{~cm}$. Although conditions were not conducive for severe leaf spot epidemics, distribution of the limited rains was more favorable for peanut production. Total rainfall at Veintiséis de Agosto was $65 \mathrm{~cm}$ during that same season but distribution of the rain events was not conducive for leaf spot epidemics or pod formation and maturization. Total rainfall for the duration of the experiment at San Pedro in 2005 was $75 \mathrm{~cm}$ but long periods of drought occurred, limiting disease development and peanut yield. Rainfall amounts and distribution were much more conducive for leaf spot epidemics at two Bolivia locations during the 2005-06 season.

\section{Results}

Disease and yield evaluations. The severity of leaf spot epidemics varied across locations and years. Early and late leaf spot were present at all U.S. locations in 2004 but early leaf spot was predominant in 2005. Across years and fungicide treatments, final defoliation ranged from 90 to $100 \%$ in Georgia Green. Early and late leaf spot were present at all Bolivian locations in both years but early leaf spot was the predominant disease in Saavedra in 2005. In Bolivia, final defoliation in nontreated plots was lower in 2005 compared with 2006. In 2005, defoliation was greatest (30\%) in plots of C-99R at Saavedra while defoliation of all genotypes at San Pedro and Veintiséis de Agosto was less than 3\%. In 2006, final defoliation in nontreated plots ranged from $75 \%$ in Georgia Green to 30\% in CRSP-01 at Veintiséis de Agosto. At Saavedra, under intense disease pressure, Georgia Green plots reached $95.3 \%$ defoliation while C-99R had the lowest defoliation at $62.5 \%$.

At all U.S. locations across both years, Bayo Grande and the CRSP breeding lines had lower AUDPC values than those of Georgia Green, C-99R, and MDR-98, except at Plains in 2005, where leaf spot levels were similar among two of the CRSP lines, C-99R, and MDR-98 (Table 1). Two applications of fungicide reduced leaf spot levels at Plains and Tifton in 2004 and Attapulgus in 2005. Although not significantly different, means at Attapulgus in 2004 and Plains in 2005 numerically followed the same trend. A fungicidegenotype interaction was significant for AUDPC in Tifton in 2005 (Table 1). Nontreated Georgia Green had the greatest AUDPC value and Bayo Grande and CRSP-08 had the lowest. The remaining genotypes were intermediate. A reduction in leaf spot intensity was seen in all genotypes with the addition of fungicide applications, and AUDPC values of all genotypes were similar when treated with the fungicide (Table 1).

In the Bolivian experiments, leaf spot epidemics were mild in the 2004-05 season and caused little defoliation in all genotypes in all locations. There were no significant differences among genotypes for disease intensity in any of the three locations (data not shown). There were no differences in AUDPC among genotypes at Saavedra in the 2005-06 season when higher levels of disease occurred (Table 2). The application of fungicide significantly suppressed leaf spot intensity at Saavedra (Table 2). Leaf spot levels were extremely low in 2005 at San Pedro, and no significant differences among the genotype or fungicide treatments were observed for disease intensity (data not shown). A fungicide-genotype interaction was observed for leaf spot intensity at Veintiséis de Agosto in both the 2004-05 season (data not shown) and the 2005-06 season (Table 2). Under low leaf spot pressure in the 2005-06 season (less than 3\% in nontreated plots), AUDPC levels in nontreated plots were similar for most of the genotypes, and the addition of fungicides only significantly suppressed leaf spot in C-

Table 1. Effect of peanut genotype and application of tebuconazole on area under the disease progress curve (AUDPC) least square means for leaf spot intensity caused by Cercospora arachidicola and Cercosporidium personatum at three locations in GA, U.S. in 2004 and $2005^{\mathrm{x}}$

\begin{tabular}{|c|c|c|c|c|c|c|c|}
\hline \multirow[b]{2}{*}{ Genotype } & \multicolumn{2}{|c|}{ Attapulgus } & \multicolumn{2}{|c|}{ Plains } & \multicolumn{3}{|c|}{ Tifton $^{y}$} \\
\hline & 2004 & 2005 & 2004 & 2005 & 2004 & 2005 NT & 2005 TEB \\
\hline Georgia Green & $33 \mathrm{a}$ & $33 \mathrm{a}$ & $71 \mathrm{a}$ & $32 \mathrm{a}$ & $53 \mathrm{a}$ & $38 \mathrm{a}$ & $6 \mathrm{ab}^{*}$ \\
\hline Bayo Grande & $12 \mathrm{~d}$ & $15 \mathrm{~d}$ & $26 \mathrm{e}$ & $6 \mathrm{~d}$ & $17 \mathrm{~d}$ & $8 \mathrm{~d}$ & $1 \mathrm{ab}^{*}$ \\
\hline CRSP-01 & $16 \mathrm{~d}$ & $19 \mathrm{c}$ & $32 \mathrm{~d}$ & $12 \mathrm{bc}$ & $24 \mathrm{c}$ & $19 \mathrm{bc}$ & $3 \mathrm{ab}^{*}$ \\
\hline CRSP-08 & $14 \mathrm{~d}$ & $15 \mathrm{~d}$ & $38 \mathrm{c}$ & $9 \mathrm{~cd}$ & $27 \mathrm{c}$ & $10 \mathrm{~d}$ & $4 a b^{*}$ \\
\hline CRSP-14 & $14 \mathrm{~d}$ & $16 \mathrm{~cd}$ & $34 \mathrm{~cd}$ & $15 \mathrm{~b}$ & $27 \mathrm{c}$ & $16 \mathrm{c}$ & $3 \mathrm{ab}^{*}$ \\
\hline C-99R & $27 \mathrm{~b}$ & $27 \mathrm{~b}$ & $46 \mathrm{~b}$ & $17 \mathrm{~b}$ & $38 \mathrm{~b}$ & $24 \mathrm{~b}$ & $4 \mathrm{ab}^{*}$ \\
\hline MDR-98 & $22 \mathrm{c}$ & $24 \mathrm{~b}$ & $50 \mathrm{~b}$ & $15 \mathrm{~b}$ & $35 \mathrm{~b}$ & $16 \mathrm{c}$ & $7 \mathrm{a}^{*}$ \\
\hline $\operatorname{LSD}(P \leq 0.05)$ & 5 & 4 & 6 & 6 & 6 & 6 & $\ldots$ \\
\hline $\mathrm{df}$ & 34 & 30 & 6 & 30 & 6 & 28 & $\ldots$ \\
\hline \multicolumn{8}{|c|}{ Fungicide treatment ${ }^{2}$} \\
\hline Nontreated & 21 & $26 \mathrm{a}$ & $47 \mathrm{a}$ & 20 & $34 \mathrm{a}$ & $\ldots$ & $\ldots$ \\
\hline Tebuconazole & 19 & $17 \mathrm{~b}$ & $38 \mathrm{~b}$ & 10 & $29 \mathrm{~b}$ & $\ldots$ & $\ldots$ \\
\hline $\operatorname{LSD}(P \leq 0.05)$ & NS & 8 & 3 & NS & 4 & $\ldots$ & $\ldots$ \\
\hline $\mathrm{df}$ & $\ldots$ & 2 & 6 & $\ldots$ & 4 & $\ldots$ & $\ldots$ \\
\hline
\end{tabular}

${ }^{\mathrm{x}} \mathrm{LSD}=$ Fisher's protected least significant difference $(P \leq 0.05)$; $\mathrm{df}=$ degrees of freedom. For Genotype and Fungicide treatment, means in a column followed by the same letter are not significantly different. NS = not significant.

y There was a significant $(P \leq 0.05)$ interaction in 2005 between fungicide and genotype. Therefore, LSD values are for comparison of genotypes within fungicide treatments; * indicates a significant difference between the nontreated (NT) and tebuconazole (TEB) treatments within a genotype. $\mathrm{LSD}=6, \mathrm{df}=28$.

${ }^{\mathrm{z}}$ Nontreated $=$ nontreated control, Tebuconazole $=$ application of tebuconazole (Folicur 3.6F; Bayer CropScience, Research Triangle Park, NC) at 0.138 kg a.i./ha at the first observation of leaf spot followed by a second application 14 days later. 
99R compared with the nontreated plots (data not shown). With an increase in disease pressure in 2005-06, Bayo Grande, MDR-98 and the CRSP lines had the lowest AUDPC levels under the nontreated control (Table 2). Georgia Green had the highest AUDPC levels and C-99R was intermediate. All genotypes responded to the fungicide treatment with lower AUDPC values. When treated with fungicide, AUDPC values were highest in Georgia Green, Bayo Grande, CRSP-14, and C-99R and lowest in CRSP-01, CRSP-08, and MDR-98 (Table 2).

Yields of in-shell peanut varied greatly across U.S. locations and years. Mean yields across genotypes were 1,036, 3,756, and 2,840 $\mathrm{kg} / \mathrm{ha}$ at Attapulgus, Plains, and Tifton, respectively, in 2004. Yields were unusually low at Attapulgus, likely due to the inadvertent application of the preplant herbicide atrazine (Shell Chemical Company, Houston) before peanut crops were planted. In 2005, yields averaged 3,304, 1,476, and 2,453 kg/ha at Attapulgus, Plains, and Tifton, respectively. Although the percentage of the inshell weight that the kernels represent was not recorded for each plot, across genotypes and fungicide treatments, kernel weight accounted for $73 \%$ of the in-shell weight, based on bulk samples of all replications from each treatment from the Tifton experiment in 2005 (data not shown). A range of 68 to $75 \%$ kernel weight would be typical for these genotypes grown in Georgia.

At Plains and Tifton in 2004, yields of Bayo Grande, C-99R, MDR-98 and the CRSP breeding lines were higher than those of Georgia Green (Table 3). At Plains, across genotypes, yields were higher in plots treated with fungicide than in nontreated plots (Table 3). A similar trend in yield was observed in Tifton, although the differences were not significant $(P>0.05)$. In 2005 , neither genotype nor fungicide significantly affected yield at any of the three U.S. locations (data not shown).

In Bolivia, mean yields of shelled peanut were 2,472, 729, and 2,653 kg/ha in Saavedra, San Pedro, and Veintiséis de Agosto, respectively, for the 2004-05 season, and 1,524 and 3,011 kg/ha in Saavedra and Veintiséis de Agosto, respectively, for the 2005-06 season. In-shell weights were also recorded for each plot in the 2004-05 season, and kernel weights represented an average of 74,

Table 2. Effect of peanut genotype and application of tebuconazole on area under the disease progress curve (AUDPC) least square means for leaf spot intensity caused by Cercospora arachidicola and Cercosporidium personatum during the 2005-06 season at two locations in Bolivia ${ }^{\mathrm{x}}$

\begin{tabular}{lccc}
\hline & & \multicolumn{2}{c}{ Veintiséis de Agosto } \\
\cline { 2 - 4 } Genotype & Saavedra & NT & TEB \\
\hline Georgia Green & 19 & $67 \mathrm{a}$ & $10 \mathrm{a}^{*}$ \\
Bayo Grande & 15 & $36 \mathrm{c}$ & $7 \mathrm{ab}^{*}$ \\
CRSP-01 & 16 & $33 \mathrm{c}$ & $3 \mathrm{~b}^{*}$ \\
CRSP-08 & 19 & $36 \mathrm{c}$ & $4 \mathrm{~b}^{*}$ \\
CRSP-14 & 18 & $37 \mathrm{c}$ & $7 \mathrm{ab}^{*}$ \\
C-99R & 12 & $44 \mathrm{~b}$ & $6 \mathrm{ab}^{*}$ \\
MDR-98 & 16 & $35 \mathrm{c}$ & $4 \mathrm{~b}^{*}$ \\
LSD $(P \leq 0.05)$ & NS & 6 & \\
df & & 28 & \\
Fungicide treatment & & & \\
Nontreated & $31 \mathrm{a}$ & $\ldots$ & $\ldots$ \\
Tebuconazole & $2 \mathrm{~b}$ & $\ldots$ & $\ldots$ \\
LSD $(P \leq 0.05)$ & 7 & $\ldots$ & \\
df & 3 & & \\
\hline
\end{tabular}

${ }^{\mathrm{x}}$ LSD $=$ Fisher's protected least significant difference $(P \leq 0.05)$; $\mathrm{df}=$ degrees of freedom. For Genotype and Fungicide treatment, means in a column followed by the same letter are not significantly different. NS = not significant.

y There was a significant $(P \leq 0.05)$ interaction between fungicide and genotype. Therefore, LSD values are for comparison of genotypes within fungicide treatments; * indicates a significant difference between the nontreated (NT) and tebuconazole (TEB) treatments within a genotype. LSD $=6, \mathrm{df}=28$.

${ }^{\mathrm{z}}$ Nontreated $=$ nontreated control, Tebuconazole $=$ application of tebuconazole (Folicur 3.6F; Bayer CropScience, Research Triangle Park, NC) at $0.138 \mathrm{~kg}$ a.i./ha at the first observation of leaf spot followed by a second application 14 days later.
37, and $73 \%$ of the total in-shell weights for Saavedra, San Pedro, and Veintiséis de Agosto, respectively.

The effect of genotype on yield was significant at Saavedra, San Pedro, and Veintiséis de Agosto in the 2004-05 season and at Veintiséis de Agosto in the 2005-06 season (Table 4). Across fungicide treatments in the 2004-05 season at Saavedra, yields of Georgia Green and C-99R were higher than those of the other genotypes (Table 4). Yields of MDR-98, Bayo Grande, and CRSP01 were lowest, while CRSP-08 and CRSP-14 were intermediate (Table 4). Across genotypes, fungicide applications improved yield (Table 4). In the same season at San Pedro, yields were low, likely due to the dry season. Across fungicide treatments, yield of Georgia Green was higher than that of any other genotype (Table 4). C-99R and CRSP-14 had intermediate yields and the remaining genotypes had the lowest yields (Table 4). There was no significant fungicide effect on yield. In the 2004-05 season at Veintiséis de Agosto, across fungicide treatments, yields of all genotypes were similar except that of CRSP-14, which was lower than those of Georgia Green, Bayo Grande, CRSP-01, and C-99R (Table 4). Fungicide did not impact yields (Table 4).

In the 2005-06 season at Veintiséis de Agosto, yields of Bayo Grande, CRSP-01, CRSP-08, and CRSP-14 were higher than that of Georgia Green, while C-99R and MDR-98 were intermediate (Table 4). Across genotypes, the fungicide treatment increased yields compared with the nontreated plots (Table 4). A fungicidegenotype interaction was significant at Saavedra in the 2005-06 season (Table 4). Under the nonsprayed treatment, the yield of C99R was greater than that of Georgia Green but was not significantly different from the other genotypes (Table 4). With the addition of the fungicide treatments, yields of Georgia Green were greater than all other genotypes except MDR-98. Yields of all genotypes except Bayo Grande and CRSP-08 increased with applications of fungicide (Table 4).

Predefoliation early leaf spot evaluations. Assessments of early leaf spot incidence began after epidemics were already underway in both years, with incidence in Georgia Green approximately $28 \%$ at the initial evaluation 87 DAP in 2002 and approximately $11 \%$ at the initial evaluation 53 DAP in 2003. Disease incidence approached $100 \%$ by the final assessment in 2002 and $80 \%$ in 2003 for Georgia Green. Genotype affected AUDPC significantly in both years (Table 5). The AUDPC values for Bayo Grande, CRSP-01, CRSP-08, CRSP-14, and C-99R were lowest in 2002, while the AUDPC value for Georgia Green was the highest. CRSP-

Table 3. Effect of peanut genotype and application of tebuconazole on least square means for yield $(\mathrm{kg} / \mathrm{ha})$ of in-shell peanuts at two locations in GA, U.S. in $2004^{\mathrm{y}}$

\begin{tabular}{lcc}
\hline Genotype & Plains & Tifton \\
\hline Georgia Green & $2,377 \mathrm{c}$ & $1,133 \mathrm{~d}$ \\
Bayo Grande & $3,920 \mathrm{ab}$ & $3,564 \mathrm{a}$ \\
CRSP-01 & $3,971 \mathrm{ab}$ & $3,286 \mathrm{ab}$ \\
CRSP-08 & $4,123 \mathrm{ab}$ & $3,635 \mathrm{a}$ \\
CRSP-14 & $4,215 \mathrm{a}$ & $3,354 \mathrm{ab}$ \\
C-99R & $4,032 \mathrm{ab}$ & $2,764 \mathrm{bc}$ \\
MDR-98 & $3,652 \mathrm{~b}$ & $2,147 \mathrm{c}$ \\
LSD $(P \leq 0.05)$ & 487 & 786 \\
df & 28 & 6 \\
Fungicide treatment & & \\
Nontreated & $3,443 \mathrm{~b}$ & 2,648 \\
Tebuconazole & $4,068 \mathrm{a}$ & 3,033 \\
LSD $(P \leq 0.05)$ & 260 & $\mathrm{NS}$ \\
df & 28 & \\
\hline
\end{tabular}

${ }^{\mathrm{y}} \mathrm{LSD}=$ Fisher's protected least significant difference $(P \leq 0.05)$; $\mathrm{df}=$ degrees of freedom. For Genotype and Fungicide treatment, means in a column followed by the same letter are not significantly different. NS = not significant.

${ }^{\mathrm{z}}$ Nontreated $=$ nontreated control, Tebuconazole $=$ application of tebuconazole (Folicur 3.6F; Bayer CropScience, Research Triangle Park, NC) at $0.138 \mathrm{~kg}$ a.i./ha at the first observation of leaf spot followed by a second application 14 days later. 
20 and MDR-98 had intermediate AUDPC values (Table 5). In 2003, Georgia Green and CRSP-01 had the highest AUDPC value, while Bayo Grande had the lowest (Table 5). The remaining genotypes were intermediate.

\section{Discussion}

Assessments of leaf spot and yield provided information on the relative resistance and production capabilities of U.S.- and Bolivian-derived peanut germplasm. Leaf spot resistance in Bayo Grande and the CRSP lines was apparent at all U.S. locations as measured by lower percent defoliation when compared with U.S. standard cv. Georgia Green. Predefoliation evaluations of early leaf spot corroborated these results; in 2002, Bayo Grande and the CRSP lines suppressed disease progress of early leaf spot compared with Georgia Green. In 2003, only Bayo Grande, CRSP-08, and CRSP-14 suppressed this portion of the epidemic compared with Georgia Green. There was no evidence that any of the breeding lines evaluated had field resistance that was better than that of Bayo Grande but most were more resistant than MDR-98.

The leaf spot field resistance observed in Bayo Grande and germplasm developed from Bayo Grande in U.S. field experiments supports the suggestion by Holbrook and Stalker (9) that peanut lines from Bolivia possess potential untapped resistance to the leaf spot pathogens. However, when these genotypes were evaluated in Bolivia, genotype effects on leaf spot epidemics were significant only at Veintiséis de Agosto in the 2005-06 season under no fungicide application. Genotype effects at Veintiséis de Agosto in the 2005-06 season were consistent with results in most of the experiments in the United States. Although low leaf spot pressure reduced the likelihood of detecting differences in the 2004-05 season experiments, severe epidemics of leaf spot developed in nontreated plots at Saavedra in the 2005-06 season. There was a trend toward more severe epidemics in Georgia Green than in C-99R and Bayo Grande at that location; however, relative response to leaf spot among the genotypes differed from that observed at Veintiséis de Agosto and in the U.S. experiments. Differential response of genotypes is common when screening for resistance to Cercospora arachidicola $(12,16,23,24)$ and Cercosporidium personatum (5), and may be due to differences in favorability of environmental conditions to disease development or variation in virulence of Cercospora arachidicola and Cercosporidium personatum isolates within populations among locations $(19,20)$. These results suggest that field resistance evaluations in the United States may not be indicative of relative resistance reactions at all Bolivian locations and vice versa. Preliminary studies of components of resistance indicate that Bayo Grande and CRSP-01, when inoculated with Cercospora arachidicola collected from U.S. locations, result in smaller-sized lesions compared with Georgia Green (data not shown). Sporulation also appears to be reduced in Bayo Grande and most of the breeding lines compared with Georgia Green (data not shown). More detailed experiments should be conducted to determine which components are responsible for the resistance observed in both U.S. and Bolivian field experiments in this study.

Yields of Bayo Grande and the CRSP lines were higher than Georgia Green and greater than or equal to C-99R and MDR-98 in two locations in the United States in 2004. Warm, wet environmental conditions during the growing season in 2005 were ideal for peanut growth, and yields at two locations were high for all genotypes. The only exception was at Plains, where Cylindrocladium black rot, caused by the soilborne fungus Cylindrocladium parasiticum Crous, M.J. Winf. \& Alfenas, was present and likely reduced yields of all entries (data not shown). In Bolivia in 2005, Georgia Green had the best yields at San Pedro, and both Georgia Green and C-99R had superior yields at Saavedra in the 2004-05 season. Most genotypes yielded similarly at Veintiséis de Agosto. The high relative yields of Georgia Green at all locations were

Table 5. Effect of peanut genotype on area under the disease progress curve (AUDPC) least square means for early leaf spot incidence caused by Cercospora arachidicola recorded during predefoliation stage of epidemics in GA, U.S. in 2002-03

\begin{tabular}{lll}
\hline & \multicolumn{2}{c}{ AUDPC } \\
\cline { 2 - 3 } Genotype & $\mathbf{2 0 0 2}$ & $\mathbf{2 0 0 3}$ \\
\hline Georgia Green & $57 \mathrm{a}$ & $34 \mathrm{a}$ \\
Bayo Grande & $27 \mathrm{~d}$ & $22 \mathrm{c}$ \\
CRSP-01 & $33 \mathrm{bcd}$ & $29 \mathrm{ab}$ \\
CRSP-08 & $30 \mathrm{~cd}$ & $27 \mathrm{bc}$ \\
CRSP-14 & $33 \mathrm{bcd}$ & $25 \mathrm{bc}$ \\
CRSP-20 & $35 \mathrm{bc}$ & $28 \mathrm{~b}$ \\
C-99R & $34 \mathrm{bcd}$ & $26 \mathrm{bc}$ \\
MDR-98 & $39 \mathrm{~b}$ & $28 \mathrm{~b}$ \\
LSD $(P \leq 0.05)$ & 8 & 6 \\
df & 14 & 14
\end{tabular}

${ }^{\mathrm{z}} \mathrm{LSD}=$ Fisher's protected least significant difference $(P \leq 0.05) ; \mathrm{df}=$ degrees of freedom.

Table 4. Effect of peanut genotype and application of tebuconazole on least square means for yield $(\mathrm{kg} / \mathrm{ha})$ of shelled peanuts at three locations during the 2005 and 2006 seasons in Bolivia ${ }^{\mathrm{w}}$

\begin{tabular}{|c|c|c|c|c|c|c|}
\hline \multirow[b]{2}{*}{ Genotype } & \multicolumn{3}{|c|}{ Saavedra $^{x, y}$} & \multirow{2}{*}{$\begin{array}{c}\text { San Pedro } \\
2005\end{array}$} & \multicolumn{2}{|c|}{ Veintiséis de Agosto $^{x}$} \\
\hline & 2005 & 2006 NT & 2006 TEB & & 2005 & 2006 \\
\hline Georgia Green & $2,924 \mathrm{a}$ & $1,050 \mathrm{~b}$ & $2,326 a^{*}$ & $1,251 \mathrm{a}$ & $2,845 \mathrm{a}$ & $1,473 \mathrm{c}$ \\
\hline Bayo Grande & $2,148 \mathrm{c}$ & $1,331 \mathrm{ab}$ & $1,626 \mathrm{c}$ & $579 \mathrm{c}$ & $2,920 \mathrm{a}$ & $3,600 \mathrm{ab}$ \\
\hline CRSP-01 & $2,160 \mathrm{c}$ & $1,302 \mathrm{ab}$ & $1,651 c^{*}$ & $537 \mathrm{c}$ & $2,684 \mathrm{a}$ & $3,195 \mathrm{ab}$ \\
\hline CRSP-08 & $2,384 b c$ & $1,291 \mathrm{ab}$ & $1,503 \mathrm{c}$ & $552 \mathrm{c}$ & $2,515 \mathrm{ab}$ & $3,741 \mathrm{a}$ \\
\hline CRSP-14 & $2,509 \mathrm{~b}$ & $1,203 a b$ & $1,591 \mathrm{c}^{*}$ & $729 \mathrm{bc}$ & $2,189 \mathrm{~b}$ & $3,287 \mathrm{ab}$ \\
\hline C-99R & $3,093 \mathrm{a}$ & $1,374 \mathrm{a}$ & $1,731 \mathrm{bc}^{*}$ & $856 \mathrm{~b}$ & $2,908 \mathrm{a}$ & $2,860 \mathrm{~b}$ \\
\hline MDR-98 & $2,087 \mathrm{c}$ & $1,318 \mathrm{ab}$ & $2,041 \mathrm{ab}^{*}$ & $601 \mathrm{c}$ & $2,510 \mathrm{ab}$ & $2,920 \mathrm{~b}$ \\
\hline $\operatorname{LSD}(P \leq 0.05)$ & 336 & 323 & 207 & 415 & 794 & $\ldots$ \\
\hline df & 30 & 24 & 30 & 30 & 26 & $\ldots$ \\
\hline \multicolumn{7}{|c|}{ Fungicide treatment ${ }^{\mathrm{z}}$} \\
\hline Nontreated & $2,093 \mathrm{~b}$ & $\ldots$ & $\ldots$ & 566 & 2,445 & $2,393 \mathrm{~b}$ \\
\hline Tebuconazole & $2,852 \mathrm{a}$ & $\ldots$ & $\ldots$ & 893 & 2,861 & $3,629 \mathrm{a}$ \\
\hline $\operatorname{LSD}(P \leq 0.05)$ & 539 & $\ldots$ & $\ldots$ & NS & NS & 425 \\
\hline $\mathrm{df}$ & 4 & $\ldots$ & $\ldots$ & $\ldots$ & $\ldots$ & 26 \\
\hline
\end{tabular}

${ }^{\mathrm{w}} \mathrm{LSD}=$ Fisher's protected least significant difference $(P \leq 0.05)$; $\mathrm{df}=$ degrees of freedom. For Genotype and Fungicide treatment, means in a column followed by the same letter are not significantly different. NS = not significant.

${ }^{x}$ For Saavedra and Veintiséis de Agosto, column headings of 2005 = the 2004-05 season and $2006=$ the 2005-06 season.

y There was a significant $(P \leq 0.05)$ interaction in 2006 between fungicide and genotype. Therefore, LSD values are for comparison of genotypes within fungicide treatments; * indicates a significant difference between the nontreated (NT) and tebuconazole (TEB) treatments within a genotype. LSD $=325$ $\mathrm{kg} / \mathrm{ha}, \mathrm{df}=24$.

${ }^{\mathrm{z}}$ Nontreated $=$ nontreated control, Tebuconazole $=$ application of tebuconazole (Folicur 3.6F; Bayer CropScience, Research Triangle Park, NC) at 0.138 kg a.i./ha at the first observation of leaf spot followed by a second application 14 days later. 
likely due to a lack of heavy leaf spot pressure in the 2004-05 season. It should also be noted that the yield of Georgia Green at San Pedro was double that of other genotypes, despite the dry conditions during the 2005 June-to-December growing season. These results indicate that, in locations with low potential for leaf spot development with little rainfall or irrigation, Georgia Green has better potential for higher yield than most other genotypes evaluated in this study. Even within the same geographical area of Bolivia, environmental conditions and pathogen dynamics warrant selection for different characteristics for dry-season production than for rainy-season production. In the 2005-06 season in Bolivia, nontreated Bayo Grande and the CRSP lines had similar or higher yields compared with C-99R and MDR-98. Across fungicide regimes, Bayo Grande and the CRSP lines had higher yields than Georgia Green at Veintiséis de Agosto.

The two-spray fungicide program, based on what is current practice for some Bolivian farmers, was effective in reducing leaf spot and increasing yields at locations in Bolivia where leaf spot pressure was moderate to high. Similar results were not observed in the United States. Leaf spot was moderate to severe at all locations across years in the United States, yet little response in leaf spot intensity or yield to fungicide treatment was observed. These results may be indicative of pathogen resistance to TEB in the United States (21). Because of cost or availability, fungicides have been rarely used in peanut production in those areas of Bolivia in the past; therefore, populations of Cercospora arachidicola and Cercosporidium personatum there have a short history of exposure to TEB.

One objective of the UFL-16 project of the USAID Peanut CRSP is to develop cultivars from the CRSP breeding lines for use in both Bolivia and U.S. agricultural programs. Overall, these results indicate that no single breeding line was consistently superior for leaf spot resistance or yield potential in all locations, and that any of the breeding lines used would have potential for release and use as a cultivar in the United States or for rainy season production in Bolivia. This study also provides evidence that the parental $\mathrm{cv}$. Bayo Grande has potential for use as a source of resistance to leaf spot pathogens. Bayo Grande was observed as having considerable variability in growth habit, pod and seed size, and shape, while the CRSP breeding lines were more uniform in these characteristics (data not shown). Although the variability of Bayo Grande makes it undesirable as a cultivar for commercial use in the United States, the apparent heterogeneity indicated by that variability may provide opportunity for selection from within Bayo Grande itself for traits that would be desirable for use in either the United States or Bolivia. Bayo Grande is continuing to be used in crosses with other genotypes, and characterization of resistance in these lines is in progress.

\section{Acknowledgments}

Support for this research was funded in part by the National Peanut Board and conducted as part of the USAID Peanut Collaborative Research and Support Program (Project UFL-16). We thank E. Cantonwine, S. Danforth, M. Heath, W. Jones, A. McKeown, S. McKeown, K. Parish, and K. Welch.

\section{Literature Cited}

1. Branch, W. D. 1996. Registration of 'Georgia Green' peanut. Crop Sci. 36:806.
2. Branch, W. D., and Hildebrand, G. L. 1989. Pod yield comparison of pureline peanut selections simultaneously developed from Georgia and Zimbabwe breeding programs. Plant Breed. 102:260-263.

3. Campbell, C. L., and Madden, L. V. 1990. Introduction to Plant Disease Epidemiology. Wiley-Interscience, New York.

4. Cantonwine, E. G., Culbreath, A. K., Stevenson, K. L., Kemerait, R. C., Brenneman, T. B., Smith, N. B., and Mullinix, B. G. 2006. Integrated disease management of leaf spot and spotted wilt of peanut. Plant Dis. 90:493500 .

5. Chiyembekeza, A. J., Gorbet, D. W., and Knauft, D. A. 1993. Comparison of components of resistance in peanut to late leafspot in different environments. Crop Sci. 33:994-997.

6. Gorbet, D. W. 2003. University of Florida peanut breeding programs. Soil Crop Sci. Soc. Fla. Proc. 58:16-18.

7. Gorbet, D. W., and Shokes, F. M. 2002. Registration of 'C-99R' peanut. Crop Sci. 42:2207.

8. Gorbet, D. W., and Shokes, F. M. 2002. Registration of 'Florida MDR 98' peanut. Crop Sci. 42:2207-2208.

9. Holbrook, C. C., and Stalker, H. T. 2003. Peanut breeding and genetic resources. Plant Breed. Rev. 22:297-356.

10. Isleib, T. G., Holbrook, C. C., and Gorbet, D. W. 2001. Use of plant introductions in peanut cultivar development. Peanut Sci. 28:96-113.

11. Jarvis, A., Ferguson, M. E., Williams, D. E., Guarino, L., Jones, P. G. Stalker, H. T., Valls, J. F. M., Pittman, R. N., Simpson, C. E., and Bramel, P. 2003. Biogeography of wild Arachis: assessing conservation status and setting future priorities. Crop Sci. 43:1100-1108.

12. Knauft, D. A., and Wynne, J. C. 1995. Peanut breeding and genetics. Adv Agron. 55:393-445.

13. McDonald, D., Subrahmanyam, P., Gibbons, R. W., and Smith, D. H. 1985. Early and Late Leaf Spots of Groundnut. International Crop Research Institute for the Semi-Arid Tropics Patancheru, Anhra Pradesh, India

14. Monfort, W. S., Culbreath, A. K., Stevenson, K. L., Brenneman, T. B., Gorbet, D. W., and Phatak, S. C. 2004. Effects of reduced tillage, resistant cultivars, and reduced fungicide inputs on progress of early leaf spot of peanut (Arachis hypogaea). Plant Dis. 88:858-864.

15. Monfort, W. S., Culbreath, A. K., Stevenson, K. L., Brenneman, T. B., and Perry, C. D. 2007. Use of resistant peanut cultivars and reduced fungicide inputs for disease management in strip-tillage and conventional tillage systems. Plant Health Progress. Online. doi:10.1094/PHP-2007-0614-01-RS.

16. Nigam, S. N., Dwivedi, S. L., and Gibbons, R. W. 1991. Groundnut breeding: constraints, achievements and future possibilities. Plant Breed. Abstr. 61:1127-1136.

17. Pande, S., and Rao Narayana, J. 2001. Resistance of wild Arachis species to late leaf spot and rust in greenhouse trials. Plant Dis. 85:851-855.

18. Porter, D. M., Smith, D. H., and Rodriguez-Kabana, R. 1982. Peanut Diseases. Pages 326-410 in: Peanut Science and Technology. H. E. Pattee and C. T. Young, eds. American Peanut Research and Education Society, Yoakum, TX.

19. Rao, P. V. S., Renard, J. L., Waliyar, F., McDonald, D., and Schilling, R. 1993. Variation in symptoms of Cercospora arachidicola isolates on some groundnut genotypes. Oleagineux 48:243-250.

20. Shew, B. B., Beute, M. K., and Sommartya, T. 1989. Components of partial resistance in peanut genotypes to isolates of Cercosporidium personatum from the United States and Thailand. Phytopathology 79:136-142.

21. Stevenson, K. L., and Culbreath, A. K. 2007. Evidence of reduced sensitivity to tebuconazole in the peanut leaf spot pathogens. (Abstr.) Proc. Am. Peanut Res. Educ. Soc. 38:52

22. USDA. 2003. Report on the status of Arachis germplasm in the United States. United States Department of Agricultural Research Service, from http://www.ars-grin.gov/npgs/cgc_reports/Status11.pdf.

23. Waliyar, F., Bosc, J. P., and Bonkoungou, S. 1993. Sources of resistance to foliar diseases of groundnut and their stability in West Africa. Oleagineux 48:283-287.

24. Waliyar, F., McDonald, D., Subba Rao, P. V., and Reddy, P. M. 1993. Components of resistance to an Indian source of Cercospora arachidicola in selected peanut lines. Peanut Sci. 20:93-96.

25. Williams, D. E. 2001. New directions for collecting and conserving peanut genetic diversity. Peanut Sci. 28:135-140. 